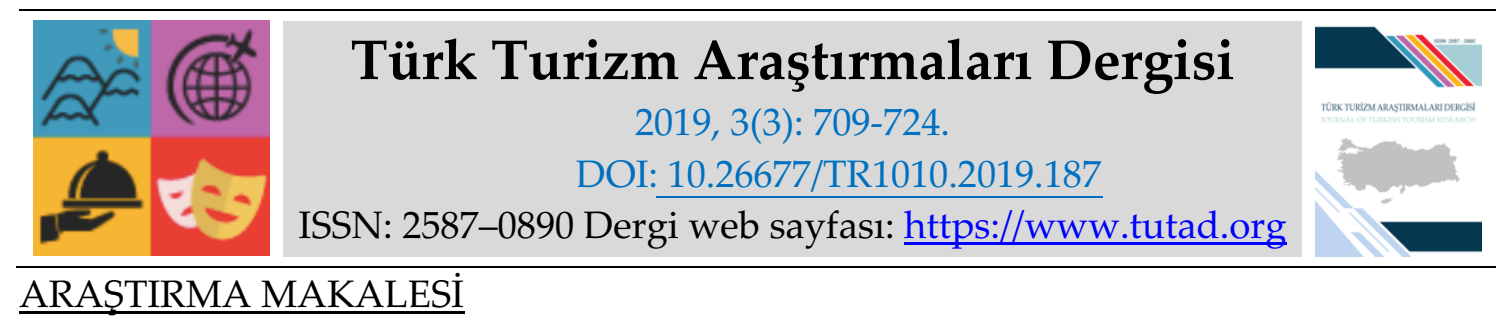

\title{
Restoran Çalışanlarının İş Yaşam Denge Düzeylerine Göre İş Tatmini ve İşten Ayrılma Niyetlerinin Karşılaştırılması
}

Arş. Gör. Ahmet ERDEM, Harran Üniversitesi, Turizm ve Otel İşletmeciliği Yüksekokulu, Şanliurfa, e-posta: ahmeterdem@harran.edu.tr

ORCID: https://orcid.org/0000-0001-8120-3958

Doç. Dr. Kamil UNUR, Mersin Üniversitesi, Turizm Fakültesi, Mersin, e-posta: kunur@mersin.edu.tr

ORCID: https://orcid.org/0000-0003-2992-7427

Arş. Gör. Ferhat ŞEKER, Mersin Üniversitesi, Turizm Fakültesi, Mersin, e-posta: ferhatseker@mersin.edu.tr

ORCID: https://orcid.org/0000-0001-6397-1232

Arş. Gör. Muhammet Abdulmecit KINIKLI, Mersin Üniversitesi, Turizm Fakültesi, Mersin, eposta: muhammetkinikli@mersin.edu.tr

ORCID: https://orcid.org/0000-0002-7789-7974

$\ddot{O} z$

Araştırmanın amacı, restoran çalışanlarının iş yaşam denge düzeylerini belirlemek ve iş yaşam denge düzeylerine göre iş tatmini ve işten ayrılma niyetinin farklılaşıp farklılaşmadığını tespit etmektir. Bu amaçla Ocak-Mart 2019 tarihleri arasında Mersin il merkezinde yer alan restoranlara gidilip, çalışanlara yüz yüze anket uygulanmıştır. Analizler, 270 kullanılabilir anket üzerinden gerçekleştirilmiştir. Kümeleme analizi sonucunda örneklem, iş yaşam dengesi düşük 151 kişi ve iş yaşam dengesi yüksek 119 kişi olmak üzere iki kümeye ayrılmıştır. Bu sonuca göre, iş yaşam dengesi düşük olan restoran çalışanlarının daha fazla olduğunu söylemek mümkündür. Demografik özelliklerden cinsiyet, çalışma saati, haftalık izin ve dini bayramlarda çalışma durumuna göre iş yaşam denge düzeyinin anlamlı farklılıklar gösterdiği tespit edilmiştir. Ayrıca, iş yaşam denge düzeyine göre hem iş tatmini hem de işten ayrılma niyeti anlamlı farklılıklar göstermektedir. İş yaşam dengesi nispeten daha yüksek olan restoran çalışanları, daha fazla iş tatminine sahiptir. Öte yandan iş yaşam dengesi nispeten daha yüksek olan çalışanların işten ayrılma niyeti daha düşüktür.

Anahtar Kelimeler: Restoran Çalışanları, İş Yaşam Dengesi, İş Tatmini, İşten Ayrılma Niyeti

Makale Gönderme Tarihi: 29.05.2019

Makale Kabul Tarihi: 05.07.2019

Önerilen Atıf:

Erdem, A., Unur, K., Şeker, F. ve Kınıklı, M. A. (2019). Restoran Çalışanlarının İş Yaşam Denge Düzeylerine Göre İş Tatmini ve İşten Ayrılma Niyetlerinin Karşılaştırılması, Türk Turizm Araştırmaları Dergisi, 3(3): 709724.

(c) 2019 Türk Turizm Araştırmaları Dergisi. 


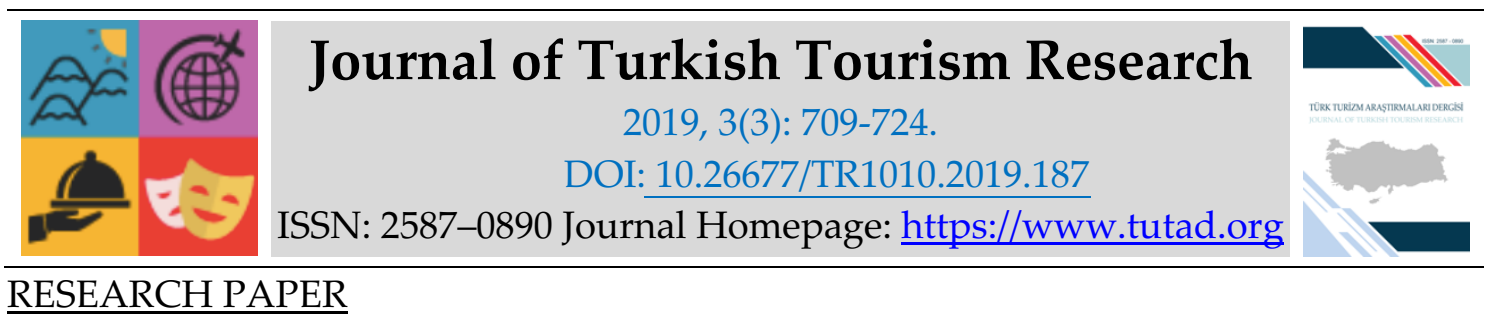

\title{
The Comparison of Restaurant Employees' Job Satisfaction and Intention to Quit in terms of Work Life Balance Levels
}

Res. Asst. Ahmet ERDEM, Harran University, School of Tourism and Hotel Management, Şanlıurfa, e-mail: ahmeterdem@harran.edu.tr ORCID: https://orcid.org/0000-0001-8120-3958

Assoc. Prof. Dr. Kamil UNUR, Mersin University, Faculty of Tourism, Mersin, e-mail: kunur@mersin.edu.tr ORCID: https://orcid.org/0000-0003-2992-7427

Res. Asst. Ferhat ŞEKER, Mersin University, Faculty of Tourism, Mersin, e-mail: ferhatseker@mersin.edu.tr ORCID: https://orcid.org/0000-0001-6397-1232

Res. Asst. Muhammet Abdulmecit KINIKLI, Mersin University, Faculty of Tourism, Mersin, email: muhammetkinikli@mersin.edu.tr

ORCID: https://orcid.org/0000-0002-7789-7974

\begin{abstract}
The aim of the study is to determine the work life balance levels of restaurant employees and to detect whether the job satisfaction and intention to quit job differ or not according to the work life balance levels. For this purpose, between January and March 2019 questionnaires were applied to the employees by face to face at the restaurants which are in the city center of Mersin. Analysis was carried out on 270 valid questionnaires. As a result of the clustering analysis, the sample of 270 restaurant employees was divided into two groups: 151 people with low level of work life balance and 119 people with high level of work life balance. According to this result, it is possible to say that the work life balance of the majority of the restaurant employees is low. It was determined that level of work life balance showed significant differences according to gender, working hours, weekly off and working at religious holidays. In addition, both job satisfaction and turnover intention differ significantly according to the level of work life balance. Restaurant workers with a relatively high level of work life balance have higher level of job satisfaction. On the other hand, workers who have a relatively high level of work life balance have low level of intention to quit job.
\end{abstract}

Keywords: Restaurant Employees, Work Life Balance, Job Satisfaction, Turnover Intention

Received: 29.05.2019

Accepted: 05.07.2019

Suggested Citation:

Erdem, A., Unur, K., Şeker, F. and Kınıklı, M. A. (2019). The Comparison of Restaurant Employees' Job Satisfaction and Intention to Quit in terms of Work Life Balance Levels, Journal of Turkish Tourism Research, 3(3): 709-724.

(C) 2019 Türk Turizm Araştırmaları Dergisi. 


\section{GİRIŞ}

Yeme içme insanoğlunun yaşamını sürdürebilmesi için karşılaması gereken en önemli gereksinimlerin başında gelmektedir (Kılınç ve Çavuş, 2010: 1). Literatürde farklı zaman dilimleri belirtilmesiyle birlikte, insanoğlu günümüzden yaklaşık 650-700 bin yıl önce ilk kez ateşi bilinçli bir şekilde ihtiyaçları doğrultusunda kullanmaya başlamıştır. Ateşin kullanılmasıyla birlikte, hayvansal ve bitkisel besinleri ateşte pişirerek tüketmeyi öğrenmiş ve besinlerin pişirilmesiyle daha kolay çiğnendiğini, lezzetli olduğunu, sindirildiğini anlamıştır (Akın ve Gültekin, 2015: 252).

Uygarlığın gelişmesi ve sınırların belirlenmesiyle Sümerler, Mısırlılar ve Romalılar gibi pek çok topluluk yaşam koşullarına, yaşadıkları coğrafyaya ve olanaklara göre kendi yemek ve mutfak kültürünü geliştirmeye başlamıştır (Korkmaz, 2010: 121). Dünyada ilk yiyecek içecek işletmesinin nerede açıldığına dair kesin bir bilgi olmamakla birlikte, 11. yüzyılda Çin'de açıldığı varsayılmaktadır (Sarışık ve Hatipoğlu, 2009). Bununla birlikte Selçuklu döneminden beri varlığı bilinen Kervansaraylar ve Hanlar konaklama ve yiyecek içecek hizmeti sunmaktaydı ve özellikle İpek Yolu üzerinde yer alan bu işletmelerin ilk yiyecek içecek işletmeleri olma olasıllı̆ 1 yüksektir (Hız, Karataş ve Öztekin Uluksar, 2015: 12). Profesyonel anlamda ilk işletmelerin Fransa'da krallık rejiminin dağılması döneminde ortaya çıktı̆̆ (Kiefer, 2002: 58) ve Boulanger adlı bir Fransız tarafından 1765 yılında ilk restoranın çorba üzerine kurulduğu kabul edilmektedir (Camillo, 2006: 30; Sarışık ve Hatipoğlu, 2009; Akoğlu ve Öztürk, 2018: 431).

Restoran kelimesi önceleri sağlık ve dinçlik veren çorba anlamında kullanılmıştır (Camillo, 2006: 30; Yıldız, 2010: 19). Türk Dil Kurumu restoran kavramını lokanta olarak tanımlamakta ve "yemek pişirilip satılan yer, aşevi, restoran" olarak açıklamaktadır. Bir başka tanımlamada ise restoran, "kuvvet ve gida veren" olarak açılanmıştır (Çiçek, 2004: 6). Günümüzde refah düzeyinin artması, kadının iş hayatına daha fazla katılımı, sosyalleşme isteği, yaşam tarzının değişmesi, moda, zevk ve keyifli bir zaman geçirme ve zamandan tasarruf etme isteği, farklı lezzetler tüketme arzusu veya ev ortamında hazırlanamayacak yiyecek içeceklerin hazır olarak elde edilme isteği (Sarışık ve Hatipoğlu, 2009: 186; Albayrak, 2014: 191) gibi çeşitli faktörler nedeniyle daha fazla kişi restoranlarda yemek yemeyi tercih etmektedir. Geçmişte aile bireyleriyle beraber ev ortamında bu tarz ihtiyaçlarını karşılayan insanlar, artık küreselleşmenin etkisiyle ve hayat standartlarında meydana gelen değişimlerle beraber yeme içme ihtiyaçlarını dışarıda hazır gıda tüketerek karşılamaktadır (Özaslan ve Uygur, 2014: 70).

Bireyler, büyük boyutlara ulaşmış olan yiyecek içecek hizmetleri endüstrisinin ürettiği ürünleri giderek artan oranlarda tüketmektedir. Bu tüketim, çağdaş tüketicilerin dışarıda yemek yeme davranışlarının bir sonucu olarak ortaya çıkmıştır (Özdemir, 2010: 218). Her geçen gün büyüyen ve ekonomideki yeri giderek artan yiyecek içecek işletmelerinde, hizmetin kalitesi ve müşteri memnuniyeti oldukça önemlidir (Koyuncu, Sünnetçioğlu ve Korkmaz, 2015: 15). Verilen hizmetin kalitesi için yiyecek kalitesi, personel kalitesi, ürünün sunum şekli, işletme ortamının bir bütün oluşturması gerekmektedir (Ünal, Akkuş ve Akkuş, 2014: 24).

Restoran işletmeleri çok sayıda ürün sunan, sürekli değişim gösteren tüketici davranışlarından etkilenen ve sektörde zincir işletmelerin yaygınlaşmasıyla rekabet şartlarının ağırlaştığı yiyecek içecek sektörü içerisinde bulunmaktadır (Bucak ve Turan, 2016: 287). Rekabetin bu denli yoğun olduğu sektörde işletmelerin varlıklarını başarılı bir şekilde sürdürmeleri için hizmet kalitesi ve misafir memnuniyeti kavramların tam anlamıyla benimsemeleri ve uygulamaları gerekmektedir (Pedraja Iglesias ve Jesus Yagüe Guillén, 2004: 373). Yiyecek ve içecek sektörünün giderek büyümesi ve diğer sektörlere göre kârlılığın daha yüksek olması, bu sektöre yatırım yapan işletmecilerin sayısının artmasına neden olmuştur (Kaya ve Serinkan, 2016: 199). Hizmet ekonomisi içerisinde önemli yeri olan ve \%40 büyüme kaydeden restoran işletmeleri (TÜRES, 
2016) yoğun rekabet ortamında çalışma şartlarını iyileştirmelidir (Albayrak, 2014: 190). Çünkü hizmetler sektörünün bir parçası olan restoranlarda hizmet kalitesi ve müşteri memnuniyetinin sağlanması için iş görenlerin memnun edilmesi gerekmektedir. Bir başka ifadeyle çalışanlar, müşteri memnuniyetini sağlamada kilit bir rol üstlenmektedir. Bu nedenle çalışma şartlarının iyileştirilmesi, çalışanların sorunları ve bu sorunların iş ve yaşam dengesiyle ilişkisi dikkate alınması gereken önemli bir konu olarak görülmektedir (Atçı, Çakıcı ve Ertaş, 2015: 162). Araştırma, böylesine önemli ve her geçen gün büyüyen sektörde faaliyet gösteren restoran çalışanlarının, iş yaşam denge düzeylerini belirlemek ve iş yaşam denge düzeylerine göre iş tatminlerini ve işten ayrılma niyetlerini ölçmek amacıyla gerçekleştirilmiştir.

\section{KAVRAMSAL ÇERÇEVE}

\section{İş Yaşam Dengesi}

İş yaşam dengesi, bir kişinin hem kişisel yaşamında hem de işinde beklentilerinin eşit olduğu bir denge halidir (The Word Spy, 2002). Ancak bu dengenin örgütlerde kurulması, günümüz yüksek tempolu iş dünyasında birçok işveren ve işçi için büyük bir sorun haline gelmiştir. Çalışanların iş yaşam dengesini kurmak, çalışanları motive etmek ve çalışanlara değerli olduklarını hissettirmek git gide zorlaşmaktadır. Lockwood'e (2003) göre iş yaşam dengesinin bu denli önemli bir faktör haline gelmesinin üç ana sebebi vardır. Bunlar, küresel rekabet (1), kişisel yaşam ya da aile değerlerine verilen önemin artması (2) ve yaşlanan işgücü (3) olarak belirtilmektedir. 1977 yılında R.M. Kanter "Amerika Birleşik Devletlerinde İş ve Aile: Eleştirel Bir İnceleme ve Araştırma/Politika için Gündem" başlıklı önemli bir kitap yayınlayarak iş yaşam dengesi konusunu örgütlerin ve araştırmacıların önüne koymuştur. Böylelikle iş yaşam dengesi kavramı 1980 'lerde literatürde sık sık yer almaya başlamıştır. Ancak teorik anlamda iş yaşam kavramı henüz bilimsel olarak araştırılmaya başlanmamış olsa da iş yaşam programları 1930'ların başında kullanılmaktaydı. İkinci Dünya Savaşı'ndan önce Amerika Birleşik Devletleri'nde W.K. Kellogg adında bir şirket üç adet sekiz saatlik vardiya yerine dört adet altı saatlik vardiya oluşturmuş ve yeni vardiya sistemi çalışanların moral ve verimliliklerini artırmıştır (Lockwood, 2003: 2).

Sao'ya (2012) göre insan hayatı dört sacayağı üzerindedir: iş, aile, arkadaşlar ve kişinin kendisi. Günümüz dünyasında bir insanın mutluluğu bu dört saçağında doğru dengeyi kurmaya bağlıdır. Örgütlerde de çalışanların bu dengeyi kurması oldukça önem arz etmektedir. Örgütlerde iş yaşam dengesi ile çalışanlarda tükenmişlik düzeyi arasında negatif yönde bir ilişkinin varlığı görülmüştür (Pichler, 2009; Chiang, Birtch ve Kwan, 2010). Chimote ve Srivastava (2013) çalışmasının sonuçlarına göre iş yaşam dengesi; devamsızlığı azaltmakta, birey ve örgüt verimliliğine pozitif etki yapmakta, sadakati ve bağlılığı sağlamakta, örgüt imajını iyileştirmekte, çalışan devir hızını azaltmakta, iş tatminini arttırmakta ve iş stresini azaltmaktadır. Benzer şekilde örgütlerde iş yaşam dengesinin kurulması, iş görenlerin moral ve verimliliklerini artırabilir, iş tatmini üzerinde olumlu, işten ayrılma niyeti üzerinde ise olumsuz bir etki sağlayabilir (Unur, Atçı, Şanlı ve Albayrak, 2018: 41). Altay ve Turunç (2018), iş yaşam dengesi ile örgütsel bağlllık arasında pozitif, iş yaşam dengesi ile işten ayrılma niyeti arasında negatif bir ilişki olduğunu bulmuştur. Tumangkeng, Tumbuan ve Tielung da (2019) yaptıkları çalışmada benzer şekilde iş yaşam dengesi ile işten ayrılma niyeti arasında ters yönlü bir ilişki olduğunu belirtmekte ve yöneticilerin bu durumu dikkate almaları gerektiğini vurgulamaktadır. 


\section{İş Tatmini}

İş tatmini, çalışanların işyerleri hakkında ne düşündüklerini ve işlerinden aldıkları memnuniyet düzeyini ifade eder (Fung-Kam, 1998). İşin özellikleri ile çalışanların istekleri uyumlu olduğu zaman iş tatmini gerçekleşmiş olur (Davis, 1988). İş tatmini kavramının literatürde sistematik bir şekilde incelenmesi 1940 'l yıllarda iş tatmininin motivasyon kuramlarında yer almasıyla başlamıştır. İş tatmini veya tatminsizliğinin neden olduğu olumlu veya olumsuz sonuçlar örgütler açısından önem arz ettiği için günümüzde halen iş tatmini araştırmaları literatürde geniş yer tutmaktadır. Çünkü, bir örgütte işleyişin bozulduğunu gösteren en önemli kanıtlardan biri iş tatmininin düşük olmasıdır (Nikolaev, Shir ve Wiklund, 2019). İş tatmini; iş performansı, işten ayrılma niyeti, hayal kırıklığ gibi tepkilerin belirleyicisi olabilir (Rusbelt, Farrell, Rogers ve Mainous,1988: 599). İş tatminiyle beraber çalışanların performansının artacağı, işte devamsızlığın azalacağ1 ve işten ayrılma niyetinin düşük olacağı düşünülmektedir (Unur ve Ertaş, 2015: 8). İş tatminsizliği ise; iş yavaşlatma, düşük verimlilik, grevler, devamsızlık, disiplin sorunları ve diğer örgütsel sorunları beraberinde getirebilir (Kahn, 1973: 94).

Restoranların da yer aldığı hizmet sektöründe çalışanların iş tatminini sağlayabilmek hizmetin kalitesinde önemli bir etkiye sahip olabilir. Yoon ve Sun (2003), iş tatmini yüksek olan çalışanların gösterdikleri performansın da yüksek olduğunu ve dolayısıyla daha çok çalışarak daha iyi hizmet sunduklarını ve örgütsel bağlılık düzeylerinin daha yüksek olduğunu ifade etmiştir. Bu nedenle örgütler, çalışanların iş tatminlerini artırmak için çeşitli yönetim teknikleri kullanmaktadır. İş tatminini artırmaya yönelik çalışmaların sonucunda, yüksek seviyede iş tatminine ulaşmış çalışanların performans ve hizmet kalitesinde olumlu gelişmeler, personel devir hızında ise azalma sağlanmıştır. (Sevimli ve İşcan, 2005). İş tatmini iş gören performansını, hizmet kalitesi ve verimliliğini, çalışan devir hızını, örgütün büyüme hızını, kurumsal itibarı ve sonuç olarak da örgütün başarısını ve varlığını uzun yıllar devam ettirmesini etkileyen önemli öğelerden birisidir (Örücü, 2005). Yapılan diğer araştırmalar iş tatmini ile tükenmişlik (Tait vd., 2012), işten ayrılma niyeti (Reukauf, 2018), devamsizlık (Scott ve Taylor, 1985) ve iş stresi (Davis ve Wilson, 2000) arasında negatif; iş tatmini ile iş yaşam dengesi (Tait vd., 2012), işe bağlllık (Gangai ve Agrawal, 2015) ve iş performansı (Judge, Thoresen, Bono ve Patton, 2001) arasında pozitif ilişkiler olduğunu göstermiştir.

\section{Isşten Ayrılma Niyeti}

İşten ayrılma niyeti, personelin çalışma koşullarından memnun olmama durumunda işten ayrılmaya yönelik düşünceye sahip olmalarıdır (Rusbelt, Farrell, Rogers ve Mainous, 1988: 599). Aynı zamanda çalışma şartlarından duyulan memnuniyetsizlik personel için işten ayrılma davranışının en büyük habercisidir (Tett ve Meyer, 1993: 259).

Bir çalışanın işten ayrılma niyeti eyleme dönüştügü zaman örgüte zarar verebileceği gibi örgüt için maliyetli de olabilir (Hom ve Griffeth, 1995; Lee ve Mitchell, 1994). Çünkü işten ayrılmalar, kalan çalışanların morallerinin düşmesine, üretilen mal veya hizmetin kalitesinde düşüş yaşanmasına, müşterilerin kaybedilmesine ve verimlilik kayıplarına sebep olarak işletmeler için önemli zararlara yol açabilir (Gim Desa ve Ramayah, 2015: 658). Ayrıca yeni personelin işe alınması, oryantasyonu, eğitimi vb. masraflar ortaya çıkacağından işletmeler ek maliyetlere katlanmak zorunda kalabilir. Bu nedenle henüz niyet aşamasındayken gerekli tedbirlerin alınması ve işten ayrılma niyetine etki eden faktörlerin iyi belirlenmesi gerekmektedir. Çünkü Schwepker (2001) işten ayrılma niyetinin fiilen iş bırakma hareketi ile pozitif ilişkili olduğunu belirtmektedir. 
Vigoda (2000) çalışmasında, işten ayrılma düşüncesi içine giren bir kişinin kafasını ve enerjisini yeni bir iş bulmaya verip hali hazırdaki görevlerini aksatabileceğini öne sürmektedir. Araştırmalar işten ayrılma niyetinin önemli ölçüde iş tatmini ile ilgili olduğunu ortaya koymuştur. Kişi eğer iş tatmini yüksek ve örgüt değerlerine bağlı ise ve bu değerlerin gerçekleştirilmesine katkıda bulunmak istiyorsa, örgütten ayrılmak istemeyecektir (Hackett, Bycio ve Hausdorf, 1994). İş yaşam dengesi ile işten ayrılma niyeti arasındaki ilişkiyi inceleyen diğer çalışmalar; iş yaşam dengesi ile işten ayrılma niyeti arasında anlamlı ve negatif bir ilişki tespit etmişlerdir. Bir başka ifadeyle çalışanın iş yaşam dengesi arttıkça işten ayrılma niyetinde azalma görülecektir (Shankar ve Bhatnagar, 2010; Yu, 2018; Jabeen, Friesen ve Ghoudi, 2018; Cheng, Nielsen ve Cutler, 2019). İşten ayrılma niyetiyle ilgili hizmet işletmelerine yönelik yapılan çalışmalar incelendiğinde, iş tatmini arttı̆̆ında işi bırakma eğiliminin azaldığı (Kaya, 2010; Chen ve Wang, 2019), çalışanların örgütsel bağlılığının iş performansı ve işten ayrılma niyetini belirleyen önemli bir etken olduğu (Akyüz ve Eşitti, 2015), işgörenlerin sahip olduğu iş stresi ile iş tatmini arasında negatif yönlü, iş stresi ile işten ayrılma niyeti arasında ise pozitif yönlü bir ilişkinin olduğu (Akova, Emiroglu ve Tanrıverdi, 2015), kurum iklimi ile işten ayrılma niyeti arasında anlamlı ve pozitif yönlü bir ilişki bulunduğu (Sökmen ve Akar Şahingöz, 2017), duygusal emek ile tükenmişlik ve işten ayrılma niyeti arasında anlamlı ilişkilerin olduğu (Karakaş, 2017) ve iş tatmini ile örgütsel bağlılık arasında pozitif yönlü, işten ayrılma niyetiyle ise negatif yönlü bir ilişki (Kong vd., 2018) olduğu belirtilmektedir. Bu çalışmada ise restoran çalışanlarının iş yaşam denge düzeyleri belirlenmiş, bazı demografik değişkenlerle iş yaşam denge düzeyi arasındaki ilişki araştırılmış ve restoran çalışanlarının iş yaşam denge düzeylerine göre iş tatmini ve işten ayrılma niyetleri karşılaştırılmıştır.

\section{YÖNTEM}

Çalışmanın temel amacı, Mersin şehir merkezinde restoran çalışanlarının iş yaşam denge düzeylerine göre iş tatmini ve işten ayrılma niyetlerinin araştırılmasıdır. Tanımlayıcı türde tasarlanan araştırmada veriler, geliştirilen bir anket ile toplanmışır. Ankette demografik soruların yanı sıra, üç de ölçek yer almaktadır. Ölçeklerden ilki McAuley, Stanton, Jolton ve Gavin tarafından 2003 yılında geliştirilen iş yaşam dengesi ölçeğidir. İkinci ölçek Brayfield ve Rothe (1951) tarafından geliştirilen iş tatmini ölçeği ve kullanılan üçüncü ölçek ise Wayne, Shore ve Linden (1997) tarafından geliştirilen işten ayrılma niyeti ölçeğidir. Ölçek maddelerinin yanıt kategorileri, " $1=$ Kesinlikle Katılmıyorum" dan başlayıp " $5=$ Kesinlikle Katıllyorum" a kadar giden 5'li derecelemeye tabi tutulmuştur.

Araştırmanın evrenini, Mersin'de faaliyet gösteren restoran çalışanları oluşturmaktadır. Mersin ilinde restoranlarda çalışan sayısı net bir şekilde belirlenemediğinden dolayı sınırsız evren formülü uygulanarak 384 asgari örneklem sayısına ulaşmak amaçlanmıştır. Bu amaç doğrultusunda veriler, kolayda örneklem yoluyla Ocak-Mart 2019 tarihleri arasında Mersin il merkezinde faaliyet gösteren restoranlardan toplanmıştır. Ancak araştırma sırasında bazen restoran sahipleri anketin doldurulmasına izin vermemiş bazen de restoran sahibi araştırmaya izin vermesine rağmen restoran çalışanı araştırmaya katılmak istememiştir. Bu nedenlerden dolayı araştırmaya gönüllü katılmak isteyen toplamda 270 restoran çalışanına ulaşılabilmiş ve anket formu yüz yüze görüşülerek uygulanmıştır.

Araştırmada kullanılan iş yaşam dengesi ölçeğinin Alfa Güvenirlik katsayısı 0,959 olarak bulunmuştur. Aynı katsayı, iş tatmini ölçeği için 0,932 ve işten ayrılmak niyeti ölçeği için 0,905 olarak hesaplanmıştır. Ölçekler ikiye ve örneklem rastgele ikiye bölünerek ve ayrıca tek ve çift numaralı ölçek maddelerine göre ölçeklerin güvenirlik katsayıları hesaplanmış ve hepsinin 0,800 'ün üstünde olduğu görülmüştür. Böylece ölçeklerin güvenilir olduğu sonucuna 
ulaşılmıştır. Elde edilen anketlere uygulanan analizlerde, tanımlayıcı istatistiklerin yanı sıra, iş yaşam denge düzeyini belirlemek amacıyla kümeleme analizinden, farklılıkların tespiti için ise ttesti ve ki-kare istatistiğinden yararlanılmıştır.

\section{BULGULAR}

Araştırmaya katılanların \%64,1'i erkek olup, \%77,4'ü evli, \%31,5'i lise mezunu ve \%48,1'i 18-26 yaş aralığındadır. Araştırmaya katılan restoran çalışanlarının \%81,1'i çocuk sahibi olmadığını belirtmiştir. Çalışanların \%80,7'si 1-10 yıl arası çalışma tecrübesine sahip olup, \%57'si günde 8-10 saat çalıştıklarını ifade etmişlerdir. Katılımcıların \%55,9'u asgari ücretle çalışmakta, \%69,6'sının sosyal güvencesi bulunmakta, \%50,4'ünün haftalık izni bulunurken, \%78,5'inin yıllık izin hakk1 bulunmamaktadır. Çalışanların \%97,4'ünün çay kahve molası varken, \%71,1'inin çalıştığ restoranda dinlenme yeri bulunmaktadır ve çalışanların \%93,3'ü çalıştı̆̆ restoranda vardiya usulünün olduğunu belirtmiştir. Son olarak katılımcıların \%52,2'si dini bayramlarda izin kullanabildiklerini belirtirken, \%77,4'ü spor yapamadığını ifade etmiştir.

Tablo 1. Katılımcıların Demografik Özelliklerine Göre Dağılımı

\begin{tabular}{|c|c|c|c|c|c|}
\hline Değişken & Frekans & $\%$ & Değişken & Frekans & $\%$ \\
\hline Cinsiyet & & & Ücret & & \\
\hline Kadın & 97 & 35,9 & Asgari Ücretten Az & 64 & 23,7 \\
\hline Erkek & 173 & 64,1 & Asgari Ücret & 151 & 55,9 \\
\hline Medeni Durum & & & Asgari Ücretten Fazla & 55 & 20,4 \\
\hline Bekar & 209 & 77,4 & Sosyal Güvence & & \\
\hline Evli & 61 & 22,6 & Evet & 188 & 69,6 \\
\hline Çocuk Sahipliği & & & Hayır & 82 & 30,4 \\
\hline Evet & 51 & 18,9 & Haftalık İzin & & \\
\hline Hayır & 219 & 81,1 & Evet & 136 & 50,4 \\
\hline Eğitim Seviyesi & & & Hayır & 134 & 49,6 \\
\hline İlköğretim & 50 & 18,5 & Y1ll1k İzin & & \\
\hline Lise & 85 & 31,5 & Evet & 58 & 21,5 \\
\hline Ön Lisans & 51 & 18,9 & Hayır & 212 & 78,5 \\
\hline Lisans ve Üzeri & 84 & 31,1 & Çay Kahve Molası & & \\
\hline Yaş & & & Evet & 263 & 97,4 \\
\hline $18-26$ yaş arası & 130 & 48,1 & Hayır & 7 & 2,6 \\
\hline 27-36 yaş arası & 105 & 38,9 & Dinlenme Yeri & & \\
\hline $37-60$ yaş arası & 35 & 13,0 & Evet & 192 & 71,1 \\
\hline Çalışma Y1lı & & & Hayır & 78 & 28,9 \\
\hline 1-10 yıl arası & 218 & 80,7 & Dini Bayramlarda İzin & & \\
\hline $11-20$ yıl arası & 36 & 13,3 & Evet & 141 & 52,2 \\
\hline 20 yıl ve üzeri & 16 & 5,9 & Hayır & 129 & 47,8 \\
\hline Çalışma Saati & & & Spor Yapma & & \\
\hline $8-10$ saat aras1 & 154 & 57,0 & Evet & 61 & 22,6 \\
\hline 11-13 saat arası & 94 & 34,8 & Hayır & 209 & 77,4 \\
\hline \multirow[t]{3}{*}{14 saat ve üzeri } & 22 & 8,1 & Vardiya Usulü & & \\
\hline & & & Evet & 252 & 93,3 \\
\hline & & & Hayır & 18 & 6,7 \\
\hline TOPLAM & 270 & 100 & TOPLAM & 270 & 100 \\
\hline
\end{tabular}


Araştırmaya katılan restoran çalışanlarının iş yaşam denge düzeylerinin belirlenmesi amacıyla iş yaşam dengesi ölçeği kullanılarak iki aşamalı kümeleme analizi gerçekleştirilmiştir. Çok boyutlu uzayda verilerin özetlenmesi ve tanımlanmasında yol gösterici bir araştırma yöntemi olan kümeleme analizi; nispeten heterojen olan farklı gruplardaki gözlem yapılarını ya da nispeten homojen olan benzer gruplardaki gözlemleri uygun yöntemlerle gruplamaya olanak sağlayan bir yöntem olarak bilinmektedir. Kümeleme analizi gözlemler arası kümelendirme, değişkenler arası sınıflandırma ya da gözlemlerin ve değişkenlerin bir arada sınıflandırılmasını amaçlar. Kümeleme analizi sonucunda 270 restoran çalışanından oluşan örneklem, iş yaşam dengesi düşük 151 kişi $(\% 55,9)$ ve iş yaşam dengesi yüksek 119 kişi $(\% 44,1)$ olmak üzere iki kümeye ayrılmıştır. Bu sonuca göre, iş yaşam dengesi düşük olan restoran çalışanlarının daha fazla olduğunu söylemek mümkündür.

Tablo 2, iş yaşam denge düzeyi ile cinsiyet arasındaki ilişkiyi ortaya koymaktadır. Buna göre, iş yaşam dengesi düşük olanların $\% 76,8^{\prime} i$ erkek iken, yalnızca $\% 23,2$ 'si kadındır. Öte yandan, iş yaşam dengesi yüksek olanların çoğunluğu $(\% 52,1)$ kadındır. Dolayısıyla, erkeklerin kadınlara kıyasla daha düşük iş yaşam dengesine sahip oldukları söylenebilir.

Tablo 2. İş Yaşam Denge Düzeyi ile Cinsiyet İliş̧kisi

\begin{tabular}{|c|l|c|c|c|}
\hline & & \multicolumn{2}{|c|}{ Cinsiyet } & \multirow{2}{*}{} \\
\hline \multirow{3}{*}{ İş Yaşam Denge Düzeyi } & & Kadın & Erkek & Toplam \\
\hline \multirow{3}{*}{ İş Yaşam Dengesi Düşük } & $\mathrm{n}$ & 35 & 116 & 151 \\
\cline { 2 - 5 } & Küme içindeki \% & $23,2 \%$ & $76,8 \%$ & $100,0 \%$ \\
\cline { 2 - 5 } & Cinsiyet içindeki \% & $36,1 \%$ & $67,1 \%$ & $55,9 \%$ \\
\hline \multirow{3}{*}{ İş Yaşam Dengesi Yüksek } & $\mathrm{n}$ & 62 & 57 & 119 \\
\cline { 2 - 5 } & Küme içindeki \% & $52,1 \%$ & $47,9 \%$ & $100,0 \%$ \\
\cline { 2 - 5 } & Cinsiyet içindeki \% & $63,9 \%$ & $32,9 \%$ & $44,1 \%$ \\
\hline
\end{tabular}

NOT: Pearson $\chi^{2}: 24,184 ;$ s.d.:1, $p<0,001$; Beklenen değeri 5'in altında olan hücre oranı: \%0,0; En küçük beklenen değer: 42,75

Kadınların evdeki sorumluluklarından dolayı çalışma hayatında erkeklere oranla iş yaşam dengesini kurmakta daha çok zorlanmaları beklendiği için bu sonuç düşündürücüdür. Bu nedenle araştırmacılarda, erkeklerin kadınlardan daha çok çalışıyor olabileceği yönünde şüphe uyanmıştır. Buradan hareketle tek başına cinsiyet ile iş yaşam dengesi arasında doğrudan bir ilişki kurmaktansa, cinsiyet ile çalışma saati arasındaki ilişki sorgulanmış ve yapılan ki kare analizi sonucu Tablo 3'de verilmiştir.

Tablo 3. Cinsiyet ile Çalışma Saati Arasındaki İlişki

\begin{tabular}{|c|l|c|c|c|c|}
\hline & & \multicolumn{3}{|c|}{ Çalışma Saati } & \multirow{2}{*}{ Toplam } \\
\hline \multirow{3}{*}{ Cinsiyet } & & $\mathbf{8 - 1 0}$ saat & $\mathbf{1 1 - 1 3}$ saat & $\mathbf{1 4}$ ve üzeri & Toplam \\
\hline \multirow{3}{*}{ Kadın } & $\mathrm{n}$ & 78 & 13 & 6 & 97 \\
\cline { 2 - 6 } & Cinsiyet içindeki $\%$ & $80,4 \%$ & $13,4 \%$ & $6,2 \%$ & $100,0 \%$ \\
\cline { 2 - 6 } & Çalışma saati içindeki \% & $50,6 \%$ & $13,8 \%$ & $27,3 \%$ & $35,9 \%$ \\
\hline \multirow{3}{*}{ Erkek } & $\mathrm{n}$ & 76 & 81 & 16 & 173 \\
\cline { 2 - 6 } & Cinsiyet içindeki \% & $43,9 \%$ & $46,8 \%$ & $9,2 \%$ & $100,0 \%$ \\
\cline { 2 - 6 } & Çalışma saati içindeki \% & $49,4 \%$ & $86,2 \%$ & $72,7 \%$ & $64,1 \%$ \\
\hline
\end{tabular}

NOT: Pearson $\chi^{2}$ : 35,165; s.d. :2, p<0,001;Beklenen değeri 5'in altında olan hücre oranı: \%0,0; En küçük beklenen değer: 
Tablo 3'e göre, kadınların \%80,4'ü, 8-10 arası çalışırken; bu oran erkeklerde $\% 43,9^{\prime}$ dur. Bir başka açıdan; 8-10 saat çalışanların \%50,6'sı kadınken, 11-13 saat arası çalışanların \%86,2'si erkektir. Bu sonuca göre erkekler daha fazla çalıştığı için daha düşük iş yaşam denge düzeyine sahip olabilir.

Çalışma saati ile iş yaşam dengesi arasında bir ilişkinin olup olmadı ğı da sorgulanmış, Tablo $4^{\prime}$ te, iş yaşam denge düzeyi ile çalışanların çalışma saati arasındaki ilişki verilmiştir. Tabloya göre iş yaşam dengesi düşük olanların \%45'i günde 11-13 saat arası çalışırken, iş yaşam dengesi yüksek olanların \%73,1'i günde 8-10 saat çalışmaktadır. Bu sonuca göre 8-10 saat arası çalışanlar, 11-13 saat arası çalışanlardan daha yüksek iş yaşam denge düzeyine sahiptir denebilir.

Tablo 4. İş Yaşam Denge Düzeyi ile Çalışma Saati İlişkisi

\begin{tabular}{|l|l|c|c|c|c|}
\hline & & \multicolumn{3}{|c|}{ Çalışma Saati } & \multirow{2}{*}{} \\
\hline \multirow{3}{*}{ İş Yaşam Denge Düzeyi } & & $\mathbf{8 - 1 0}$ saat & $\mathbf{1 1 - 1 3}$ saat & $\mathbf{1 4}$ ve üzeri & Toplam \\
\hline \multirow{3}{*}{ İş Yaşam Dengesi Düşük } & $\mathrm{n}$ & 67 & 68 & 16 & 151 \\
\cline { 2 - 6 } & Küme içindeki \% & $44,4 \%$ & $45,0 \%$ & $10,6 \%$ & $100,0 \%$ \\
\cline { 2 - 6 } & Çalışma saati içindeki \% & $43,5 \%$ & $72,3 \%$ & $72,7 \%$ & $55,9 \%$ \\
\hline \multirow{3}{*}{ İş Yaşam Dengesi Yüksek } & $\mathrm{n}$ & 87 & 26 & 6 & 119 \\
\cline { 2 - 6 } & Küme içindeki \% & $73,1 \%$ & $21,8 \%$ & $5,0 \%$ & $100,0 \%$ \\
\cline { 2 - 6 } & Çalışma saati içindeki \% & $56,5 \%$ & $27,7 \%$ & $27,3 \%$ & $44,1 \%$ \\
\hline
\end{tabular}

NOT: Pearson $\chi^{2}: 22,431 ;$ s.d. : $2, \mathrm{p}<0,001$;

Beklenen değeri 5 'in altında olan hücre oranı: \%0,0;

En küçük beklenen değer: 9,70

Tablo 5, iş yaşam denge düzeyi ile çalışanların haftalık izinlerinin olup olmaması arasındaki ilişkiyi özetlemektedir. Tabloya göre iş yaşam dengesi düşük olanların $\% 56,3$ 'ünün haftalık izin hakları yokken, iş yaşam dengesi yüksek olanların $\% 58,8$ 'inin haftalık izin hakları vardır. Buna göre, haftalık izin hakkına sahip olan çalışanların olmayanlardan daha yüksek iş yaşam denge düzeyine sahip olduğu söylenebilir.

Tablo 5. İş Yaşam Denge Düzeyi ile Haftalık İzin İlişkisi

\begin{tabular}{|c|l|c|c|c|}
\hline & & \multicolumn{2}{|c|}{ Haftalık İzin } & \multirow{2}{*}{ Toplam } \\
\hline \multirow{3}{*}{ İş Yaşam Denge Düzeyi } & & Var & Yok & Ṫş Yaşam Dengesi Düşük \\
\cline { 2 - 5 } & $\mathrm{n}$ & 66 & 85 & 151 \\
\cline { 2 - 5 } & Küme içindeki \% & $43,7 \%$ & $56,3 \%$ & $100,0 \%$ \\
\cline { 2 - 5 } & Haftalık izin içindeki \% & $48,5 \%$ & $63,4 \%$ & $55,9 \%$ \\
\hline \multirow{3}{*}{ İş Yaşam Dengesi Yüksek } & $\mathrm{n}$ & 70 & 49 & 119 \\
\cline { 2 - 5 } & Küme içindeki \% & $58,8 \%$ & $41,2 \%$ & $100,0 \%$ \\
\cline { 2 - 5 } & Haftalık izin içindeki \% & $51,5 \%$ & $36,6 \%$ & $44,1 \%$ \\
\hline
\end{tabular}

NOT: Pearson $\chi^{2}:$ 6,082; s.d.:1, $\mathrm{p}<0,05$;

Beklenen değeri 5 'in altında olan hücre oranı: \%0,0;

En küçük beklenen değer: 59,06

Tablo 6, iş yaşam denge düzeyi ile çalışanların dini bayramlarda izin kullanabilip kullanamadıkları arasındaki ilişkiyi özetlemektedir. Tabloya göre iş yaşam dengesi düşük olanların \%55'inin dini bayramlarda izin hakları yokken, iş yaşam dengesi yüksek olanların $\% 61,3$ 'ünün dini bayramlarda izin hakları vardır. Buna göre, dini bayramlarda izin hakkına sahip 
olan çalışanların olmayanlardan daha yüksek iş yaşam denge düzeyine sahip olduğu söylenebilir.

Tablo 6. İş Yaşam Denge Düzeyi ile Dini Bayramlarda İzin Kullanabilme İlişkisi

\begin{tabular}{|c|l|c|c|c|}
\hline & & \multicolumn{2}{|c|}{$\begin{array}{c}\text { Dini Bayramlarda } \\
\text { İzin Hakk1 }\end{array}$} & \multirow{2}{*}{ Toplam } \\
\hline \multirow{2}{*}{ İş Yaşam Denge Düzeyi } & & Var & Yok & \multicolumn{1}{|c|}{ Tom } \\
\hline \multirow{3}{*}{ İş Yaşam Dengesi Düşük } & $\mathrm{n}$ & 68 & 83 & 151 \\
\cline { 2 - 5 } & Küme içindeki \% & $45,0 \%$ & $55,0 \%$ & $100,0 \%$ \\
\cline { 2 - 5 } & Dini Bayram içindeki \% & $48,2 \%$ & $64,3 \%$ & $55,9 \%$ \\
\hline \multirow{3}{*}{ İş Yaşam Dengesi Yüksek } & $\mathrm{n}$ & 73 & 46 & 119 \\
\cline { 2 - 5 } & Küme içindeki \% & $61,3 \%$ & $38,7 \%$ & $100,0 \%$ \\
\cline { 2 - 5 } & Dini Bayram içindeki \% & $51,8 \%$ & $35,7 \%$ & $44,1 \%$ \\
\hline
\end{tabular}

NOT: Pearson $\chi^{2}:$ 7,097; s.d.:1, $\mathrm{p}<0,05$;

Beklenen değeri 5'in altında olan hücre oranı: \%0,0;

En küçük beklenen değer: 56,86

Tablo 7, iş yaşam denge düzeylerine göre restoran çalışanlarının iş tatmini karşılaştırmasını göstermektedir. Tabloya göre, iş tatmini, iş yaşam dengesi yüksek olan çalışanlarla düşük olan çalışanlar arasında anlamlı farklılıklar göstermektedir $(\mathrm{p}<0,05)$. İş yaşam dengesi nispeten daha yüksek olan restoran çalışanları, iş tatminine daha yüksek ortalama atamışlardır $(3,8067)$. Başka bir ifade ile, iş yaşam dengesi yüksek olan çalışanlar düşük olan çalışanlardan daha fazla iş tatminine sahiptirler.

Tablo 7. İş Yaşam Denge Düzeyine Göre İş Tatmini Karşılaştırılması

\begin{tabular}{|c|lll|l|l|c|c|c|}
\hline & \multicolumn{3}{|c|}{ Küme } & N & Ortalama & Std. Sapma & t-değeri & p-değeri \\
\hline \multirow{3}{*}{ İŞ TATMiNi } & $\begin{array}{l}\text { İş̧ Yaşam } \\
\text { Düşük }\end{array}$ & Denge & Düzeyi 151 & 3,1965 & 1,18025 & & \multirow{2}{*}{4,821} & 0,000 \\
\cline { 2 - 6 } & $\begin{array}{l}\text { İş Yaşam } \\
\text { Yüksek }\end{array}$ & Denge & Düzeyi 119 & 3,8067 & 0,89936 & 4 \\
\hline
\end{tabular}

Son olarak Tablo 8, iş yaşam denge düzeylerine göre restoran çalışanlarının işten ayrılma niyeti karşılaştırmasını göstermektedir. Tabloya göre, işten ayrılma niyeti, iş yaşam dengesi yüksek olan çalışanlarla düşük olan çalışanlar arasında yine anlamlı farklılıklar vardır $(\mathrm{p}<0,05)$. İş yaşam dengesi nispeten daha yüksek olan restoran çalışanlarının işten ayrılma niyeti ortalamaları daha düşüktür $(3,0364)$. Yani iş yaşam dengesi nispeten daha yüksek olan restoran çalışanları işten ayrılmayı daha az düşünmektedirler. Öte yandan iş yaşam denge düzeyi düşük olanların işten ayrılma niyet ortalamaları, iş yaşam denge düzeyi yüksek olanlardan daha fazladır $(3,3620)$.

Tablo 8. İş Yaşam Denge Düzeyine Göre İşten Ayrılma Niyeti Karşılaştırılması

\begin{tabular}{|c|c|c|c|c|c|c|}
\hline & Küme & $\mathbf{N}$ & Ortalama & Std. Sapma & t-değeri & p-değeri \\
\hline \multirow{2}{*}{$\begin{array}{l}\text { İŞTEN AYRILMA } \\
\text { NIYYETİ }\end{array}$} & $\begin{array}{l}\text { İş Yaşam Denge Düzeyi } \\
\text { Düşük }\end{array}$ & 151 & 3,3620 & 1,28636 & \multirow{2}{*}{2,092} & \multirow{2}{*}{0,037} \\
\hline & $\begin{array}{l}\text { İş Yaşam Denge Düzeyi } \\
\text { Yüksek }\end{array}$ & 119 & 3,0364 & 1,24782 & & \\
\hline
\end{tabular}


Bu bulgulardan haraketle çalışma saatleri uzun, haftalık izin hakkı olmayan ve dini bayramlarda izin kullanamayan çalışanların iş yaşam dengeleri düşmekte, bu da çalışanların iş tatminini düşürmekte ve işten ayrılma niyetlerini artırmaktadır denebir. Bir başka ifade ile daha kısa çalışma süreleri, haftalık izin hakkı, dini bayramlarda izin kullanabilme, restoran çalışanlarının iş yaşam denge düzeylerinin ve iş tatminlerinin yükselmesini, işten ayrılma niyetlerinin azalmasını sağlamaktadır yorumu yapılabilir.

\section{TARTIŞMA, SONUÇ VE ÖNERILER}

Mersin il merkezinde faaliyet gösteren restoranlarda çalışan 270 kişi üzerinde gerçekleştirilmiş olan bu çalışma, restoran çalışanlarının iş yaşam denge düzeylerini belirlemek ve iş yaşam denge düzeylerine göre iş tatminlerinin ve işten ayrılma niyetlerinin farklılaşıp farklılaşmadığını tespit etmek amacıyla gerçekleştirilmiştir. Ayrıca bazı demografik değişkenlere göre çalışanların iş yaşam denge düzeylerinin nasıl farklılaştığı da çalışmada incelenmiştir.

Analiz sonuçlarına göre, erkeklerin kadınlara kıyasla daha düşük iş yaşam dengesine sahip oldukları görülmüştür. Literatürde, çalışma hayatına giren kadınların evdeki sorumluluklarından dolayı erkeklere oranla iş yaşam dengesini kurmakta daha çok zorlandıkları görülmektedir (Korkmaz ve Erdoğan, 2014: 544). Bu nedenle cinsiyet ile çalışma saati arasında bir ilişkinin varlığından şüphe edilmiş ve cinsiyet ile çalışma saati arasında bir ilişkinin varlığ 1 tespit edilmiştir. Buna göre erkeklerin kadınlardan daha uzun mesai saatlerine sahip olduğu görülmüştür. Bunun da iş yaşam denge düzeyini olumsuz etkilediği çıkarımı yapılmıştır. Çünkü çalışma saati ile iş yaşam dengesi arasındaki ilişkinin sorgulandığı analiz sonuca göre 8-10 saat arası çalışanların, 11-13 saat arası çalışanlardan daha çok iş yaşam dengesine sahip oldukları tespit edilmiştir. Çalışma saati arttıkça iş ile özel hayat arasında denge kurmak zorlaşacağından böyle bir sonucun çıkması normal karşılanabilir. Subramaniam, Overton ve Maniam (2015)'e göre esnek çalışma saati düzenlemelerinin, iş yaşam dengesini arttırma ihtimali vardır. Sandor'un (2011) Avrupa'da kısmi zamanlı çalışanlar üzerine yapmış olduğu şirket araştırmasında, kısmi zamanlı çalışanların iş yaşam düzeylerinin tam zamanlı çalışanlara kıyasla daha yüksek olduğu sonucu elde edilmiştir. Benzer bir sonuç, Al (2016) tarafından da ortaya konmuştur Buna göre; kısmi zamanlı çalışanlarla tam zamanlı çalışanların bireysel performans düzeyleri ve iş tatminlerinin araştırıldığı çalışmada, bulgular, kısmi zamanlı çalışanların işlerinden duydukları tatminlerin ve ortaya koydukları bireysel performansların tam zamanlı çalışanlardan yüksek olduğunu göstermiştir.

Yapılan başka bir ki-kare analizi sonucunda iş yaşam denge düzeyi ile gelir seviyesi ve iş yaşam düzeyi ile sosyal güvencenin varlığı arasında anlamlı bir ilişki olmadığı tespit edilmiştir. Bu bulgudan hareketle çalışanların ister az kazansın ister çok kazansın her durumda iş ve yaşamları arasında denge kurmak istedikleri yorumu yapılabilir. İnsanları birer makine gibi gören klasik yönetim teorilerinde olduğu gibi, daha fazla para vererek bir çalışanı daha fazla çalışmaya ikna etmek mümkün olsa da çok çalışan insanların işleri ve yaşamları arasında denge kurmakta zorlandıkları görülmektedir. Sosyal güvenceyle iş yaşam dengesi arasında bir ilişki çıkmamasının nedenlerinden birisi insanların sosyal güvencenin varlığını da bir mükâfat olarak değil de bir zorunluluk olarak görmeleri olabilir. Ayrıca, iş yaşam denge düzeyi ile diğer demografik değişkenler (medeni durum, eğitim seviyesi, çocuk sahibi olma durumu, yaş, çalışma yılı, vardiya usulü, yıllık izin, çay kahve molası, dinlenme yeri ve spor yapma durumu) arasında istatistiksel olarak anlamlı ilişkiler tespit edilememiştir. 
İş yaşam denge düzeyi ile çalışanların haftalık izinlerinin olup olmaması arasındaki ilişkinin araştırıldığı analiz sonucuna göre, haftalık izni olanlar olmayanlardan nispeten daha fazla iş yaşam dengesine sahiptir. Haftalık izin hakkına sahip olan çalışanların kısa süreliğine de olsa işten uzaklaşıp kendilerine vakit ayırabildikleri için iş yaşam dengesi kurmada daha başarılı oldukları yorumu yapılabilir. Çalışmanın bir başka amacına yönelik olarak restoran çalışanlarının iş yaşam denge düzeylerini belirlemek için iki aşamalı kümeleme analizi gerçekleştirilmiştir. Yapılan kümeleme analizi sonucunda 270 restoran çalışanından oluşan örneklem, iş yaşam dengesi düşük 151 kişi $(\% 55,9)$ ve iş yaşam dengesi yüksek 119 kişi $(\% 44,1)$ olmak üzere iki kümeye ayrılmıştır. Bu sonuca göre, araştırmaya katılan restoran çalışanlarının çoğunluğunun iş yaşam dengesinin düşük olduğunu söylemek mümkündür. Bu sonucun nedenleri ve bu sonuçların nasıl düzeltilebileceği araştırılmalıdır.

İş yaşam dengesi nispeten daha yüksek olan restoran çalışanları, iş tatminine daha yüksek ortalama atamışlardır $(3,8067>3,1965)$. Öte yandan iş yaşam dengesi nispeten daha yüksek olan çalışanların işten ayrılma niyeti ortalamaları daha düşüktür $(3,0364<3,3620)$. Ancak işten ayrılma niyetindeki ortalama farkı, iş tatmininde olduğu kadar yüksek değildir. İş yaşam dengesi kurmada zorlanan ve buna bağlı olarak iş tatmini de düşük olan çalışanların, işten ayrılma niyetleri eşit oranda artmamaktadır. Bu durumun arkasında mevcut ekonomik koşullar altında yeni bir iş bulmanın zorlukları, iş değiştirmenin işverenler tarafından hoş karşılanmaması, insanların alışkın olduğu örgütü değiştirmeyi risk olarak algılaması gibi sebepler yatabilir.

Sonuç olarak restoran çalışanlarının çalışma saatlerinin uzun olmaması, haftalık izin haklarının bulunması ve dini bayramlarda izin kullanabilmeleri önerilebilir. Aksi takdirde çalışma sonuçları göstermektedir ki uzun çalışma saatleri, haftalık izin hakkının olmaması ve dini bayramlarda çalışma zorunluluğu restoran çalışanlarında iş yaşam denge düzeyinin azalmasına sebep olmaktadır. Azalan iş yaşam denge düzeyi de yine araştırma bulgularına göre, iş tatminini düşürmekte ve işten ayrılma niyetini artırmaktadır.

\section{KAYNAKÇA}

Akın., G., ve Gültekin, T. (2015). Günümüz Restoran Tasarımında Kriterler, Mühendislik Bilimleri ve Tasarm Dergisi, 3(3): 251-258.

Akoğlu, A. ve Öztürk, E. (2018). Türkiye'de Fine Dining Restoranlara Bakış: Mutfak Yöneticileri Üzerine Bir Araştırma, Journal of Tourism and Gastronomy Studies, 6(1): 430-443.

Akova, O., Emiroglu, B. D. and Tanriverdi, H. (2015). Satisfaction and turnover intent: A study at five-star hotels in Istanbul, Journal of Management Marketing and Logistics, 2(4): 378-402.

Akyüz, B., ve Eşitti, B. (2015). Hizmet İşletmelerinde örgütsel bağlılı̆̆ın iş performansı ve işten ayrılma niyeti üzerindeki etkisi: Çanakkale örnekleminde bir araştırma, Bartın Üniversitesi İ̈BF Dergisi, 6(11): 23-39.

Al, A. D. (2016). Kısmi Zamanlı Çalışanlarla Tam Zamanlı Çalışanların Bireysel Performans Düzeylerinde İş Tatmininin Rolü, Yüksek Lisans Tezi, Marmara Üniversitesi, Sosyal Bilimler Enstitüsü, İstanbul.

Albayrak, A. (2014). Müşterilerin restoran seçimlerini etkileyen faktörler: İstanbul örneği, Anatolia: Turizm Araştırmaları Dergisi, 25(2): 190-201.

Altay, M., ve Turunç, Ö. (2018). İş Yükü, Çalışma Yaşam Kalitesi ve İşten Ayrılma Niyeti İlişkisi: Lider-Üye Etkileşiminin ve Örgütsel Bağlllığın Aracılık Rolü, Kafkas Üniversitesi İktisadi ve İdari Bilimler Fakültesi Dergisi, 9(17): 191-229. 
Atçı, D., Çakıcı A.C. ve Ertaş, Ç. (2015). Fast-Food çalışanlarının iş sorunlarının iş ve yaşam tatminlerine etkisi: Mersin şehir merkezinde bir araştırma. Anadolu Üniversitesi Sosyal Bilimler Dergisi, 15(1): 161-173.

Brayfield, A. and Rothe, H. (1951). An Index of Job Satisfaction, Journal of Applied Psychology, 35, 307-311.

Bucak, T. ve Turan, Ö. (2016). Restoranlarda Hizmet Kalitesinin Misafir Memnuniyetine Etkisi: Çanakkale Merkezinde Bir Araştırma, The Journal of Academic Social Science Studies, 49: 287-304.

Camillo, A. A. (2006). Exploratory Study of the Historical Development and Trend Analysis of Restaurant Cuisine (Doctoral dissertation, Oklahoma State University).

Chen, H. T. and Wang, C. H. (2019). Incivility, satisfaction and turnover intention of tourist hotel chefs: moderating effects of emotional intelligence, International Journal of Contemporary Hospitality Management.

Cheng, Z., Nielsen, I. and Cutler, H. (2019). Perceived job quality, work-life interference and intention to stay: Evidence from the aged care workforce in Australia, International Journal of Manpower.

Chiang, F. F., Birtch, T. A. and Kwan, H. K. (2010). The moderating roles of job control and worklife balance practices on employee stress in the hotel and catering industry, International Journal of Hospitality Management, 29(1): 25-32.

Chimote, N. K., and Srivastava, V. N. (2013). Work-life balance benefits: From the pers- pective of organizations and employees, IUP Journal of Management Research, 12(1): 62-73.

Çiçek, A. (2004). Türkçeye Giren Fransızca Kökenli Bazı Kelimeler Üzerine Bir İnceleme, Atatürk Üniversitesi Türkiyat Araştırmaları Enstitüsü Dergisi, 11(24): 1-9.

Davis, J. and Wilson, S.M. (2000). Principals' efforts to empower teachers: Effects on teacher motivation and job satisfaction and stress, The Clearing House: A Journal of Educational Strategies, Issues and Ideas, 73(6): 349-353.

Davis, K. (1988). İ̧̧letmede insan davranışı: Örgütsel davranış (K. Tosun ve diğerleri, Çev.). İstanbul: İstanbul Üniversitesi.

Fung-kam. L. (1998). Job satisfaction and autonomy of Hong Kong registered nurses, Journal of Advanced Nursing, 27(2): 355-363.

Gangai, K.N. and Agrawal, R. (2015). Job Satisfaction and Organizational Commitment: Is It important for Employee Performance, International Journal of Management and Business Research, 5 (4): 269-278.

Gim, G. C., Desa, N. M. and Ramayah, T. (2015). Competitive psychological climate and turnover intention with the mediating role of affective commitment. Procedia - Social and Behavioral Sciences, (172): 658-665.

Hackett, Bycio and Hausdorf (1994). Further Assessments of Meyer And Allen's (1991) Three Component Model of Organizational Commitment, Jornal of Applied Psychology, 79(1): 15-24.

Hom, P.W. and Griffeth, R.W. (1995). Employee Turnover, South Western, Cincinnati, OH.

Hız, G., Karataş, A. ve Öztekin Uluksar, F. (2015). Konaklama işletmelerinde mutfakta istihdam edilenlerin tükenmişlik sendromu: Marmaris Örneği, Muğla Sıtkı Koçman Üniversitesi İktisadi ve İdari Bilimler Fakültesi Ekonomi ve Yönetim Araştırmaları Dergisi, 4(2): 8-29.

http://tures.org.tr/ (Erişim Tarihi: 06/05/2019). 
Jabeen, F., Friesen, H.L. and Ghoudi, K. (2018). Quality of work life of Emirati women and its influence on job satisfaction and turnover intention: Evidence from the UAE, Journal of Organizational Change Management, 31(2): 352-370.

Judge, T. J., Thoresen, C. J., Bono, J. E. and Patton, G. K. (2001). The job satisfaction- job performance relationship: A qualitative and quantitative review, Psychological Bulletin, 127(3): 376-407.

Kahn, L.R. (1973). The Work Module: A Tonic for Lunchpail Lassitude, Psyschology Today, February.

Kanter, R. M. (1977). Work and family in the United States: A critical review and agenda for research and policy. New York: Russell Sage Foundation.

Karakaş, A. (2017). Duygusal emek, tükenmişlik ve işten ayrılma niyeti arasındaki ilişki: Otel işletmesi çalışanları üzerine bir araştırma, İ̧̧letme Araştırmaları Dergisi, 9(1): 80-112.

Kaya., İ. (2010). Otel İşletmelerinde İşgörenlerin İş Tatminini Etkileyen İşi Bırakma Eğilimi, Çukurova Üniversitesi Sosyal Bilimler Enstitüsü Dergisi, 19(2): 219-236.

Kaya., M. ve Serinkan., C. (2016). Yiyecek İçecek İşletmelerinin İşgören İstihdamında Etkili Olan Faktörler: Bişkek Türk İşletmeleri Örneği. 7th International Congress on Entrepreneurship Bishkek, Kyrgyzstan, 197-212.

Kong, H., Jiang, X., Chan, W., and Zhou, X. (2018). Job satisfaction research in the field of hospitality and tourism, International journal of contemporary hospitality management, 30(5): 21782194.

Kılınç., O. ve Çavuş Ş. (2010). Profesyonel Restoran Yönetimi Ilkeler, Uygulamalar ve Örnek Olaylar içinde Ed. Sarıı̧ık M., Çavuş, Ş. ve Karamustafa, K., Detay Yayıncılık., Ankara

Kiefer, N. M. (2002). Economics and the Origin of the Restaurant, Cornell Hotel and Restaurant Administration Quarterly, 43(4): 58-64.

Korkmaz, E. (2010). Geçmişten Günümüze Restoranlar: Türkiye'de Restorancllı̆̆ın Gelişimi, V. Lisansüstü Turizm Öğrencileri Araştırma Kongresi: 120-130.

Korkmaz, H., Sünnetçioğlu, S. ve Koyuncu, M. (2015). Duygusal Emek Davranışlarının Tükenmişlik ve İşten Ayrılma Niyeti İle İlişkisi: Yiyecek İçecek Çalışanları Üzerinde Bir Araştırma, Mehmet Akif Ersoy Üniversitesi Sosyal Bilimler Enstitüsü Dergisi, 7(12): 14-33.

Korkmaz, O. ve Erdoğan, E. (2014). İş Yaşam Dengesinin Örgütsel Bağlllık ve Çalışan Memnuniyetine Etkisi, Ege Akademik Bakış, 14(4): 541-557.

Lee, T.W. and Mitchell, T.R. (1994). An alternative approach: the unfolding model of voluntary employee turnover, The Academy of Management Review, 19(1): 51-89.

Lockwood, N.R. (2003). Work/Life Balance Challenges and Solutions, Society for Human Resource Management Report, USA.

McAuley, G.F., Stanton, J.M., Jolton, J.A. and Gavin, J. (2003). Modeling the Relationship between Work/Life Balance and Organizational Outcomes, Annual Conference of the Society for IndustrialOrganizational Psychology, April, Orlando.

Nikolaev, B., Shir, N. and Wiklund, J. (2019). Dispositional Positive and Negative Affect and SelfEmployment Transitions: The Mediating Role of Job Satisfaction. Entrepreneurship Theory and Practice: $1-24$. 
Örücü, E. (2005). Konaklama İşletmelerinde İş Gören Tatminini Etkileyen Faktörler. Sosyal ve Ekonomik Araştırmalar Dergisi: 145-146.

Özaslan, Y. ve Uygur, S. M. (2014). Negatif Ağızdan Ağıza İletişim (Wom) ve Elektronik Ağıdan Ağıza İletişim (E-Wom): Yiyecek-İçecek İşletmelerine Yönelik Bir Araştırma, Ataturk University Journal of Economics \& Administrative Sciences, 28(3): 69-88.

Özdemir, B. (2010). Dışarıda Yemek Yeme Olgusu: Kuramsal Bir Model Önerisi, Anatolia: Turizm Araştırmaları Dergisi, 21(2): 218-232.

Pichler, F. (2009). Determinants of work-life balance: Shortcomings in the contemporary measurement of WLB in large-scale surveys. Social Indicators Research, 92(3): 449-469.

Pedraja Iglesias, M. and Jesus Yagüe Guillén, M. (2004). Perceived quality and price: their impact on the satisfaction of restaurant customers, International Journal of Contemporary Hospitality Management, 16(6): 373-379.

Reukauf, J.A. (2018). The Correlation Between Job Satisfaction and Turnover Intention in Small Business. Walden University, College of Management and Technology, Dissertations and Doctoral Studies.

Rusbelt, Farrell, Rogers and Mainous, (1988). Impact of Exchange Variables on Exit, Voice, Loyalty and Neglect: An Integrative Model of Responses to Decline Job Satisfaction, Academy of Management Journal, 31(3): 599-627.

Sandor, E. (2011). European Company Survey 2009 Part-time work in Europe. European Foundation for the Improvement of Living and Working Conditions.

Sao, R. (2012). Work Life Balance in Today's World: A Necessitate for All, Indian Streams Research Journal, (2): 1-4.

Sarışık, M. ve Hatipoğlu, A. (2009). Türkiye'de Yiyecek İçecek Sektörünün Gelişimi. Editörler, Çavuş vd. Türk Turizm Tarihi, Yapısal ve Sektörel Gelişim, Detay Yayıncılık, Ankara.

Schwepker, C.H. (2001). Ethical Climate's Relationship to Job Satisfaction, Organizational Commitment and Turnover Intention in The Sales Force, Journal of Business Research, (54): 39-52.

Scott, K. D. and Taylor, G. S. (1985). An examination of conflicting findings on the relationship between job satisfaction and absenteeism: A meta-analysis, The Academy of Management Journal, 28(3): 599-612.

Sevimli, F. ve İşcan, Ö. F. (2005). Bireysel Ve İş Ortamına Ait Etkenler Açısından İş Tatmini. Ege Akademik Bakış, 5 (1): 55-64.

Shankar, T. and Bhatnagar, J. (2010). Work Life Balance, Employee Engagement, Emotional Consonance/Dissonance \& Turnover Intention, Indian Journal of Industrial Relations, 46 (1): 74-87.

Sökmen, A. ve Şahingöz, S. A. (2017). Kadın Çalışanlarda Cam Tavan Yansıtıcılarından Kurum İkliminin, İş Tatmini Ve İşten Ayrılma Niyetine Etkisi: Otel İşletmelerinde Bir Araştırma, İşletme Araştırmaları Dergisi, 9(1): 113-133.

Subramaniam, A. G., Overton, B. J. and Maniam, C. B. (2015). Flexible Working Arran- gements, Work Life Balance and Women in Malaysia. International Journal of Social Science and Humanity, 5(1): 34-38.

Tait, D.D., Sonja, B., Litjen, T., Lotte, N.D., Wayne, S., Daniel, S., Colin, P.W., Jeff, S. and Micheal R.O. (2012). Burnout and Satisfaction with Work-Life Balance Among US Physicians Relative to the General US Population, American Medical Association, 172(18): 1377-1385. 
Tett, R.P. and Meyer, J.P. (1993). Job satisfaction, organizational commitment, turn over intention and turn over: Pathanalyses based on meta-analytic findings. Personnel Psychology, 1(46): 259-293.

Tumangkeng, E. G., Tumbuan, W. J. and Tielung, M. V. (2019). Influence of Work Life Balance and Income Towards Employee Turnover Intention at Murex Dive Resort Manado. Journal EMBA: Journal Riset Ekonomi, Manajemen, Bisnis dan Akuntansi, 7(2).

Türk Dil Kurumu (2019). Lokanta. Erişim tarihi: 26.05.2019. http://sozluk.gov.tr/

Unur, K., Atçı, D., Şanlı, C. ve Albayrak, Z. (2018). Ekmek Fırını Çalışanları Üzerine Keşifsel Bir Araştırma: Mersin Örneği, Gastroia: Journal of Gastronomy and Travel Research, 2(1): 39-51.

Unur, K. ve Ertaş, Ç. (2015). Mersin Şehir Merkezindeki Lüks Restoranlarda Çalışan Servis Personelinin Sorunlarının Tespiti ve Bu Sorunların İş Tatminine Etkisi, Seyahat ve Otel İşletmeciliği Dergisi, 12 (1): 6-24.

Ünal, S., Akkuş, G. ve Akkuş, Ç. (2014). Yiyecek içecek işletmelerinde atmosfer, duygu, memnuniyet ve davranışsal sadakat ilişkisi, Gazi Üniversitesi Turizm Fakültesi Dergisi, 1(1): 23-49.

Vigoda, E. (2000). Organizational politics, job attitudes, and work outcomes: Exploration and implications for the public sector. Journal of Vocational Behavior,57: 326 -347.

Wayne, S. J., Shore, L. M. and Liden, R. C. (1997). Perceived organizational support and leadermember exchange: A social exchange perspective, Academy of Management Journal, 40(1): 82-111.

Yıldız, E. (2010). Restoran İşletmelerine Giriş. Profesyonel Restoran Yönetimi Ilkeler, Uygulamalar ve Örnek Olaylar içinde Ed. Sarışık M., Çavuş, Ş. ve Karamustafa, K., Detay Yayıncılık., Ankara.

Yoon, M. H. and Suh. (2003). Organizational citizenship behaviours and service quality as external effectiveness of contact employees, Journal of Business Research, 56 (8): 597-611.

Yu, H.H. (2018). Work-Life Balance: An Exploratory Analysis of Family-Friendly Policies for Reducing Turnover Intentions Among Women in U.S. Federal Law Enforcement, International Journal of Public Administration, 42(4): 345-357.

www.wordspy.com/words/work-lifebalance (Erişim Tarihi: 29/04/2019). 